DOI: $10.15193 /$ zntj/2019/120/298

\author{
LIDIA PIEKARSKA-RADZIK, ELŻBIETA KLEWICKA, JOANNA MILALA, \\ ROBERT KLEWICKI, NATALIA ROSÓŁ, BOŻENA MATYSIAK, \\ MICHAŁ SÓJKA, JAROSŁAW MARKOWSKI
}

\title{
WPLYW POLIFENOLI Z WYTLOKÓW Z PSEUDOOWOCÓW ROSA RUGOSA THUNB. NA WZROST BAKTERII Z RODZAJU LACTOBACILLUS
}

\begin{abstract}
Streszczenie
Polifenole jako metabolity wtórne roślin stanowią podstawową barierę dla mikroflory uznanej za chorobotwórczą i patogenną (wirusy, grzyby, bakterie). Spożywane wraz z pokarmem zdolne są do wywołania wielu pozytywnych efektów w organizmach ssaków (zwierząt i człowieka) oraz ptaków. Przypisuje im się nie tylko właściwości przeciwutleniające, ale także obniżające ciśnienie, przeciwzapalne oraz przeciwdrobnoustrojowe. Tym samym niestrawione polifenole docierając do jelit w znacznym stopniu odpowiadają za modulację mikroflory jelitowej (w tym bakterii z rodzaju Lactobacillus). Jedną z roślin, która zawiera dużo związków polifenolowych jest Rosa rugosa Thunb. - jeden z najpopularniejszych gatunków dzikiej róży występujący na terenie Polski.

Celem pracy była ocena potencjału prebiotycznego ekstraktów polifenolowych surowych i oczyszczonych otrzymanych z wytłoków z pseudoowoców Rosa rugosa Thunb. w stosunku do bakterii z rodzaju Lactobacillus (w tym szczepów o potwierdzonych właściwościach probiotycznych). Dominującymi grupami polifenoli obecnymi w ekstraktach były elagotaniny i procyjanidyny. W ekstraktach stwierdzono również obecność wolnego kwasu elagowego, flawonoli i wolnych katechin. Ponadto ekstrakty oczyszczone charakteryzowały się znacznie większą zawartością polifenoli w porównaniu z ekstraktami surowymi. Przeprowadzono również badania potencjału prebiotycznego zliofilizowanych ekstraktów w stosunku do bakterii z rodzaju Lactobacillus (w tym szczepu Lactobacillus brevis ŁOCK 0944 o potwierdzonych właściwościach probiotycznych). W badaniach zastosowano metodę turbidymetryczną. Potencjał prebiotyczny w stosunku do bakterii z rodzaju Lactobacillus wykazywały jedynie polifenole w stężeniu $0,156 \mathrm{mg} / \mathrm{ml}$. Powyżej tego stężenia polifenole zawarte w wytłokach z pseudoowoców Rosa rugosa Thunb. działały jako czynnik ograniczający przyrost biomasy bakterii z rodzaju Lactobacillus.
\end{abstract}

Mgr inż. L. Piekarska-Radzik, prof. dr hab. inż. E. Klewicka, Instytut Technologii Fermentacji i Mikrobiologii, Wydz. Biotechnologii i Nauk o Żywności. Politechnika Łódzka, ul. Wólczańska 171/173, dr inż. J. Milala, dr hab. inż. R. Klewicki, prof. nadzw., mgr inż. N. Rosół, dr inż. M. Sójka, Instytut Technologii i Analizy Żywności, Wydz. Biotechnologii i Nauk o Żywności. Politechnika Łódzka, ul. Stefanowskiego 4/10, 90-924 Łódź, dr hab. B. Matysiak, prof. nadzw., dr hab. J. Markowski, prof. nadzw., Instytut Ogrodnictwa, ul. Konstytucji 3 Maja 1/3, 96-100 Skierniewice.

Kontakt: lidia.piekarska@edu.p.lodz.pl 
Słowa kluczowe: Lactobacillus sp., wzrost bakterii, Rosa rugosa Thunb., polifenole

\section{Wprowadzenie}

Rodzaj Rosa (należący do rodziny Rosacea) obejmuje 120 - 200 gatunków rozpowszechnionych głównie w strefie umiarkowanej i subtropikalnej na półkuli północnej $[2,16]$. Wśród licznych gatunków można wyróżnić m.in. Rosa rugosa (znaną również jako róża pomarszczona, karbowana, japońska, fałdzistolistna), występującą na terenie południowo-wschodniej Polski, w Japonii, Chinach, na Kamczatce, Sachalinie oraz na Półwyspie Koreańskim [18, 22].

Ze względu na morfologię Rosa rugosa zaliczana jest do szczeciniastych i gęstych krzewów. Osiąga do 2 metrów wysokości. Pędy Rosa rugosa pokrywają nierówne kolce oraz włoski. Liśce są duże - do $22 \mathrm{~cm}$, szarozielone od spodu i błyszczące $\mathrm{z}$ wierzchu [21]. W okresie kwitnienia Rosa rugosa wytwarza różowe kwiaty (o różnym natężeniu barwy; niekiedy białe), charakteryzujące się wyraźnym zapachem [29]. Pseudoowoce Rosa rugosa są zazwyczaj czerwonej lub szkarłatnej barwy. Przybierają kształt kulisty, butelkowaty lub wydłużony. Wielkością przypominają groch lub orzechy [21]. Wspólną cechą rodzaju Rosa jest unikatowy typ reprodukcji. To, co zazwyczaj nazywane jest „owocem róży”, w rzeczywistości stanowi zbiór owoców. Tym samym tworzy tak zwany „pseudoowoc”, w którym twarde orzeszki (będące owocem właściwym) znajdują się wewnątrz mięsistej i barwnej okrywy [2, 3, 21, 30]. Owoce Rosa rugosa są powszechnie wykorzystywane w gastronomii i ziołolecznictwie. W związku $\mathrm{z}$ dużą zawartością witaminy $\mathrm{C} \quad \mathrm{w}$ świeżych owocach $(1200 \div$ $2500 \mathrm{mg} / 100 \mathrm{~g}$ ) przypisuje się im działanie moczopędne, przeciwszkorbutowe i przede wszystkim przeciwutleniające [4]. Ponadto ekstrakty z Rosa spp. zawierają dużo związków organicznych, takich jak: karotenoidy, olejki eteryczne, cukry, nienasycone kwasy tłuszczowe, kwasy organiczne. Szeroka gama związków polifenolowych izolowanych z owoców Rosa rugosa obejmuje między innymi terpenoidy, fenole, tokoferole, flawonoidy, garbniki i antocyjany $[9,17]$.

Ekstrakty z Rosa spp. wykazują nie tylko dużą aktywność przeciwutleniającą, ale także właściwości: przeciwalergiczne, obniżające ciśnienie, przeciwcukrzycowe, przeciwzapalne, przeciwwirusowe, przeciwdrobnoustrojowe [25]. Tym samym preparaty z Rosa spp. zdolne są do hamowania rozwoju bakterii i grzybów uznanych za patogenne i zanieczyszczające żywność. W literaturze znajdują się doniesienia świadczące o tym, że ekstrakty ograniczają rozwój gatunków, takich jak: Escherichia coli, Staphylococcus aureus, Enterococcus faecalis, Candida albicans [31].

Róża jest często stosowana do produkcji olejków eterycznych, kosmetyków, perfum [9]. Liczne przemysłowe zastosowania owoców rodzaju Rosa spowodowały, że 
W wielu środowiskach może dochodzić do interakcji między polifenolami zawartymi w owocach a mikroorganizmami. Jedną z matryc, która bez wątpienia może łączyć metabolity wtórne roślin oraz bakterie z rodzaju Lactobacillus jest żywność [3].

Celem pracy była ocena potencjału prebiotycznego ekstraktów polifenolowych otrzymanych z wytłoków z pseudoowoców Rosa rugosa Thunb. w stosunku do bakterii z rodzaju Lactobacillus (w tym szczepów o potwierdzonych właściwościach probiotycznych).

\section{Material i metody badań}

Materiał biologiczny stanowiły 3 szczepy bakterii z rodzaju Lacobacillus: Lactobacillus acidophilus ŁOCK 0928, Lactobacillus brevis ŁOCK 0944 (szczep o potwierdzonych właściwościach probiotycznych - PL 214504, B1) [10], Lactobacillus casei ŁOCK 0979, które zostały zdeponowane w Kolekcji Czystych Kultur Przemysłowych ŁOCK105 w Instytucie Technologii Fermentacji i Mikrobiologii Politechniki Łódzkiej.

Mrożone wytłoki z pseudoowoców Rosa rugosa Thunb. (Polska Róża, Falenty Nowe) poddawano 0,5-godzinnej ekstrakcji wodnej w stosunku $1: 2(\mathrm{v} / \mathrm{v})$. Następnie wytłoki ekstrahowano dwukrotnie statycznie przez $24 \mathrm{~h} \mathrm{z}$ użyciem 60-procentowego roztworu acetonu lub 60-procentowego etanolu w stosunku $1: 3(\mathrm{v} / \mathrm{v})$. Otrzymane ekstrakty etanolowe i acetonowe zatężano w wyparce próżniowej (Hei-VAP Precision, Heidolph, Schwabach, Niemcy). Następnie zatężone ekstrakty acetonowe lub etanolowe dzielono na 2 części. Jedną z nich poddawano oczyszczaniu z użyciem chromatografii kolumnowej na złożu Amberlite XAD 1600 N (kopolimer diwinylobenzenu). Ekstrakty surowe i oczyszczone poddawano suszeniu sublimacyjnemu z użyciem liofilizatora (Christ, Alpha 1-2 LDplus, Osterode am Harz, Niemcy). W otrzymanych liofilizowanych ekstraktach oznaczano zawartość wybranych grup polifenoli: elagotanin, flawonoli i flawanoli z użyciem metod chromatograficznych HPLC opisanych przez Milalę i wsp. [16] oraz Kosmalę i wsp. [12]. Elagotaniny i flawonole oznaczano przy użyciu chromatografu Dionex z detektorem Dionex DAD (Dionex, USA) i kolumną Gemini 5u C18 110A $250 \mathrm{~mm} \times$ 4,6 mm, $5 \mu \mathrm{m}$. Do oznaczania flawanoli stosowano natomiast chromatograf Knauer Smartline (Knauer, Niemcy) z detektorem Knauer UVVis P2800 i detektorem Shimadzu RF-10AXL (Shimadzu, Japonia) oraz kolumną Gemini 5u C18 110A $250 \mathrm{~mm} \times 4,6 \mathrm{~mm}, 5 \mu \mathrm{m}$ ).

Ocenę aktywności oddziaływania potencjalnie prebiotycznego badanych ekstraktów w stosunku do bakterii z rodzaju Lactobacillus wykonywano metodą turbidymetryczną. Analizie poddawano cztery ekstrakty z wytłoków z pseudoowoców Rosa rugosa Thunb.: acetonowy surowy i oczyszczony oraz etanolowy surowy i oczyszczony, o końcowym stężeniu polifenoli w zakresie $0,156 \div 0,625 \mathrm{mg} / \mathrm{ml}$. W tym celu zliofilizowane ekstrakty rozpuszczano w mieszaninie wody destylowanej i DMSO (dimetylosulfotlenek; Sigma, USA) w stosunku $1: 2$ (v/v). 
Dynamikę wzrostu bakterii z rodzaju Lactobacillus w obecności polifenoli zawartych w ekstraktach z wytłoków z pseudoowoców Rosa rugosa Thunb. prowadzono z wykorzystaniem płytki 96-dołkowej do mikrotestów (Thermo Scientific, USA). W tym celu do studzienki w mikroteście wprowadzano $20 \mu 1$ 10-krotnie zatężonego podłoża MRS (de Man, Rogosa and Sharpe - MERCK, Niemcy) oraz $170 \mu 1$ przygotowanych wcześniej płynnych ekstraktów, których stężenie w studzience wynosiło [mg/ml]: 0,156, 0,313 i 0,625. Przygotowane w ten sposób studzienki zaszczepiano $10 \mu \mathrm{l}$ 24-godzinnej hodowli bakterii z rodzaju Lactobacillus (o gęstości komórek $10^{9} \mathrm{jtk} / \mathrm{ml}$ ). Próby kontrolne zamiast ekstraktów z wytłoków z pseudoowoców Rosa rugasa Thunb. dopełniano do $200 \mu \mathrm{l}$ wodą destylowaną. Do dołków wprowadzano również po $170 \mu \mathrm{l}$ ekstraktów, $20 \mu \mathrm{l}$ 10-krotnie stężonego podłoża MRS oraz $10 \mu \mathrm{l}$ podstawowego podłoża MRS. Przygotowane w ten sposób próby posłużyły jako tło metody.

Zaszczepione płytki 96-dołkowe poddawano inkubacji w temperaturze optymalnej do wzrostu badanych mikroorganizmów. Pomiaru absorbancji przy $\lambda=560 \mathrm{~nm}$ dokonywano w czasie $\mathrm{t}=0,3,5,9,12,24,30,48 \mathrm{~h}$ za pomocą automatycznego czytnika mikropłytek (TriStar2 S LB 942, Berthold Technologies, Niemcy). Wyniki przedstawiano $\mathrm{w}$ postaci współczynnika przyrostu biomasy ( $\triangle \mathrm{A} 560)$ obliczonego $\mathrm{z}$ równania:

$$
\Delta \mathrm{A} 560=\mathrm{A}_{\mathrm{tn}}-\mathrm{A}_{\mathrm{t}=0}
$$

gdzie: $\mathrm{A}_{\mathrm{t}=0}$ - ilość biomasy użyta do zaszczepienia hodowli, $\mathrm{A}_{\mathrm{tn}}$ - ilość biomasy w kolejnych jednostkach czasu.

Uzyskane wyniki badań przedstawiono jako wartości średnie z co najmniej trzech powtórzeń. Poddano je analizie statystycznej za pomocą testu istotności różnic ANOVA $\mathrm{z}$ testem post-hoc Kruskala-Wallisa $(\mathrm{p}=0,05) \mathrm{w}$ przypadku obliczenia współczynnika przyrostu biomasy oraz za pomocą testu ANOVA z testem post-hoc Dunkana $(\mathrm{p}=0,05) \mathrm{w}$ przypadku określania zawartości polifenoli w ekstraktach. Obliczenia wykonywano w programie Statistica 12 (StatStoft, Polska).

\section{Wyniki i dyskusja}

\section{Analiza ilościowa i jakościowa ekstraktów}

W tab. 1. przedstawiono skład polifenolowy otrzymanych ekstraktów: surowych i oczyszczonych. Ekstrakty różniły się istotnie zawartością polifenoli, przy czym ekstrakty surowe charakteryzowały się znacznie mniejszą zawartością związków polifenolowych niż ekstrakty oczyszczone. Zawartość polifenoli w ekstraktach surowych wynosiła odpowiednio: 8,8 g/100 g s.m. (ekstrakt etanolowy) i 14,9 g/100 g s.m. (ekstrakt acetonowy), a w ekstraktach oczyszczonych: 29,2 g/100 g s.m. (ekstrakt etanolowy) i 33,2 g/100 g s.m. (ekstrakt acetonowy). W ekstraktach wykazano obecność grupy 
związków polifenolowych: kwasu elagowego i elagotanin, flawanoli (procyjanidyn i wolnych katechin) i flawonoli.

Dominującą grupę polifenoli obecną w ekstraktach otrzymanych z wytłoków z pseudoowoców Rosa rugosa Thunb. stanowiły elagotaniny. Ich udział w zależności od sposobu otrzymania ekstraktu wynosił $52 \div 58 \%$. W ekstraktach obecny był również wolny kwas elagowy, którego zawartość nie przekraczała $2 \%$. Dane literaturowe potwierdzają obecność tej grupy związków w różach. Według Fecka [8] średnia zawartość elagotanin w owocach róży mieści się w zakresie $43 \div 126 \mathrm{mg} / 100 \mathrm{~g}$ s.m., miąższ owoców róży zawiera ich natomiast $92 \div 248 \mathrm{mg} / 100 \mathrm{~g}$ s.m. Koponen i wsp. [11] podają natomiast, że zawartość elagotanin w owocach Rosa rugosa wynosi do $110 \mathrm{mg} / 100 \mathrm{~g}$ świeżego surowca.

Tabela 1. Skład polifenolowy ekstraktów z wytłoków z pseudoowoców Rosa rugosa Thunb.

Table 1. Content of phenolics in extracts obtained from Rosa rugosa Thunb. pseudofruit

\begin{tabular}{|c|c|c|c|c|}
\hline \multirow[t]{2}{*}{$\begin{array}{l}\text { Związek } \\
\text { Compound }\end{array}$} & $\begin{array}{c}\text { Ekstrakt } \\
\text { etanolowy, } \\
\text { surowy } \\
\text { Ethanolic } \\
\text { extract, crude }\end{array}$ & $\begin{array}{c}\text { Ekstrakt } \\
\text { etanolowy, } \\
\text { oczyszczony } \\
\text { Ethanolic } \\
\text { extract, purified }\end{array}$ & $\begin{array}{c}\text { Ekstrakt } \\
\text { acetonowy, } \\
\text { surowy } \\
\text { Acetone extract, } \\
\text { crude }\end{array}$ & $\begin{array}{c}\text { Ekstrakt } \\
\text { acetonowy, } \\
\text { oczyszczony } \\
\text { Acetone extract, } \\
\text { purified }\end{array}$ \\
\hline & \multicolumn{4}{|c|}{$\begin{array}{l}\text { Zawartość związków polifenolowych } \\
\text { Polyphenolic compounds content }[\mathrm{mg} / 100 \mathrm{~g} \mathrm{s.m./d.m.]}\end{array}$} \\
\hline $\begin{array}{l}\text { Elagotaniny } \\
\text { Ellagitannins }\end{array}$ & $4714,3^{a} \pm 53,8$ & $\begin{array}{l}15379,7^{\mathrm{c}} \\
\pm 1344,9 \\
\end{array}$ & $8649,1^{b} \pm 727,1$ & $\begin{array}{l}17680,9^{\mathrm{c}} \\
\pm 1141,2 \\
\end{array}$ \\
\hline $\begin{array}{c}\text { Wolny kwas elagowy } \\
\text { Free ellagic acid }\end{array}$ & $168,1^{\mathrm{a}} \pm 4,5$ & $496,6^{c} \pm 40,1$ & $278,7^{\mathrm{b}} \pm 32,4$ & $645,8^{d} \pm 29,8$ \\
\hline $\begin{array}{l}\text { Flawonole } \\
\text { Flavonols }\end{array}$ & $357,5^{\mathrm{a}} \pm 71,1$ & $993,7^{b} \pm 105,7$ & $603,2^{\mathrm{a}} \pm 55,3$ & $978,4^{\mathrm{b}} \pm 142,7$ \\
\hline $\begin{array}{l}\text { Procyjanidyny } \\
\text { Procyanidins }\end{array}$ & $3377,5^{\mathrm{a}} \pm 87,6$ & $10750,1^{c} \pm 6,0$ & $5144,3^{\mathrm{b}} \pm 35,2$ & $12475,5^{\mathrm{d}} \pm 39,5$ \\
\hline $\begin{array}{l}\text { Wolne katechiny } \\
\text { Free catechins }\end{array}$ & $196,2^{\mathrm{a}} \pm 12,2$ & $1529,6^{\mathrm{c}} \pm 38,5$ & $205,5^{\mathrm{a}} \pm 6,9$ & $1399,9^{\mathrm{b}} \pm 5,0$ \\
\hline $\begin{array}{l}\text { Suma oznaczonych } \\
\text { związków } \\
\text { polifenolowych } \\
\text { Total of measured } \\
\text { polyphenolic } \\
\text { compounds } \\
\text { [g/100 g s.m./d.m.] }\end{array}$ & 8,8 & 29,2 & 14,9 & 33,2 \\
\hline
\end{tabular}

Objaśnienia / Explanatory notes:

$\mathrm{W}$ tabeli przedstawiono wartości średnie \pm odchylenia standardowe / Table shows mean values \pm standard deviation; a - d - wartości średnie oznaczone różnymi literami różnią się statystycznie istotnie $(\mathrm{p} \leq 0,05)$ / mean values denoted by different letters differ statistically significantly $(\mathrm{p} \leq 0.05)$. 
Drugą dominującą grupę związków polifenolowych w otrzymanych ekstraktach stanowiły procyjanidyny, których udział wynosił $35 \div 38 \%$. Teleszko i wsp. [24] podają, że zawartość polimerów procyjanidyn w owocach Rosa rugosa przekracza $25600 \mu \mathrm{g} / \mathrm{g}$ s.m. W badaniach własnych zawartość glikozydów flawonoli w ekstraktach wynosiła $357 \div 993 \mathrm{mg} / 100$ g s.m., przy czym udział w ekstraktach surowych był o $40 \div 75 \%$ mniejszy niż w ekstraktach oczyszczonych. Cunja i wsp. [6] oraz Milala i wsp. [16] wykazują obecność powyższych związków w pseudoowocach róż, a oznaczane zawartości poszczególnych składników wahają się między 41,2 $117 \mathrm{mg} / 100 \mathrm{~g}$ s.m. w zależności od odmiany róż.

\section{Wplyw ekstraktów na wzrost bakterii z rodzaju Lactobacillus}

Na przyrost biomasy bakterii $L b$. acidophilus ŁOCK 0928 wpływ miało nie tylko stężenie polifenoli zawartych w ekstrakcie z wytłoków z pseudoowoców Rosa rugosa Thunb., ale także sam sposób ekstrakcji. Polifenole zawarte w ekstraktach wodnoetanolowych w stężeniu $0,156 \mathrm{mg} / \mathrm{ml}$ niezależnie od stopnia oczyszczenia ekstraktu miały zdolność do stymulacji stopnia namnożenia biomasy bakterii Lb. acidophilus ŁOCK 0928. Zarówno przy dodatku ekstraktu wodno-etanolowego surowego, jak i oczyszczonego, przyrost biomasy bakterii był o ponad $14 \%$ większy niż w hodowli kontrolnej. Tym samym $w$ hodowlach prowadzonych $\mathrm{z}$ dodatkiem polifenoli zawartych w ekstraktach wodno-etanolowych biomasa nie przeszła w fazę zamierania, tak jak w hodowlach kontrolnych. Dodatek polifenoli zawartych w ekstraktach wodnoacetonowych do hodowli bakterii $L b$. acidophilus ŁOCK 0928 skutkował natomiast niższym stopniem namnożenia biomasy w porównaniu z hodowlą kontrolną. Polifenole w stężeniu $0,156 \mathrm{mg} / \mathrm{ml}$ zawarte w ekstrakcie wodno-acetonowym surowym dodane do hodowli bakterii $L b$. acidophilus ŁOCK 0928 spowodowały, że przyrost biomasy w 12. h inkubacji był wyraźnie mniejszy niż w hodowli kontrolnej (o blisko $20 \%$ ). Tym samym bakterie przechodząc w fazę stacjonarną, nie były w stanie namnożyć się do poziomu zbliżonego do hodowli kontrolnej. Z kolei polifenole $\mathrm{w}$ stężeniu $0,156 \mathrm{mg} / \mathrm{ml}$ zawarte w ekstrakcie wodno-acetonowym oczyszczonym dodane do hodowli bakterii $L b$. acidophilus ŁOCK 0928 przyczyniły się do osiągnięcia przez biomasę fazy stacjonarnej $\mathrm{w}$ drugiej dobie. Hodowla $\mathrm{z}$ dodatkiem polifenoli $\mathrm{w}$ stężeniu $0,156 \mathrm{mg} / \mathrm{ml}$ zawartych $\mathrm{w}$ ekstrakcie wodno-acetonowym oczyszczonym osiągnęła podobny poziom do ilości biomasy w hodowli kontrolnej (rys. 1A).

Dwukrotne zwiększenie stężenia polifenoli (do $0,313 \mathrm{mg} / \mathrm{ml}$ ) spowodowało, że we wszystkich badanych przypadkach stopień namnożenia biomasy był niższy w przypadku hodowli z dodatkiem ekstraktu niż w hodowli kontrolnej. Polifenole w znacznym stopniu wydłużyły czas trwania fazy adaptacyjnej szczepu $L b$. acidophilus ŁOCK 0928 (do $5 \mathrm{~h}$ ). W ciągu kolejnych $2 \mathrm{~h}$ inkubacji przyrost biomasy był prawie 10-krotny. $\mathrm{W}$ ciągu następnych $13 \mathrm{~h}$ biomasa przyrosła 2-krotnie. Stopień namnożenia biomasy 
ulegał zwiększeniu do 48 godziny inkubacji. Mimo tego był prawie 2-krotnie mniejszy niż w hodowli kontrolnej (tab. 2).

Polifenole w stężeniu $0,625 \mathrm{mg} / \mathrm{ml}$ zawarte w ekstraktach z wytłoków z pseudoowoców Rosa rugosa Thunb. w znacznym stopniu ograniczyły wzrost bakterii $L b$. acidophilus ŁOCK 0928 (tab. 2).

Polifenole w stężeniu $0,156 \mathrm{mg} / \mathrm{ml}$ zawarte w ekstraktach z wytłoków z pseudoowoców Rosa rugosa Tunb. zarówno stymulowały przyrost biomasy bakterii $L b$. brevis ŁOCK 0944, jak i stały się czynnikiem obniżającym stopień namnożenia biomasy w zależności od zastosowanej procedury ekstrakcji. Różnice we wzroście bakterii z dodatkiem ekstraktów z wytłoków z pseudoowoców Rosa rugosa Thunb. widoczne były od 12 . h prowadzenia hodowli. W 24 . h hodowli ekstrakty: wodno-acetonowy surowy oraz wodno-etanolowy oczyszczony spowodowały, że przyrost biomasy był większy o ok. $7 \div 10 \%$ niż w hodowli kontrolnej. Z kolei ekstrakty: wodno-acetonowy oczyszczony i wodno-etanolowy surowy przyczyniły się do tego, że biomasa bakterii Lb. brevis ŁOCK 0944 przyrosła na zdecydowanie niższym poziomie (o $6 \div 12 \%$ ) (rys. 1B).

Dwukrotne podwyższenie stężenia polifenoli (do $0,313 \mathrm{mg} / \mathrm{ml}$ ) spowodowało, że dodatek ekstraktów wpłynął na obniżenie stopnia namnożenia biomasy w porównaniu z hodowlą kontrolną (tab. 2).

Gdy stężenie polifenoli osiągnęło 0,625 mg/ml bakterie Lb. brevis ŁOCK 0944 nie były zdolne do wzrostu po dodaniu do hodowli ekstraktu wodno-acetonowego oczyszczonego oraz wodno-etanolowego surowego. Poziom namnożenia biomasy $\mathrm{z}$ dodatkiem polifenoli (o stężeniu $0,625 \mathrm{mg} / \mathrm{ml}$ ) zawartych $\mathrm{w}$ ekstraktach: wodnoetanolowym oczyszczonym oraz wodno-acetonowym surowym był natomiast ponad 4-krotnie mniejszy niż w hodowli kontrolnej (tab. 2).

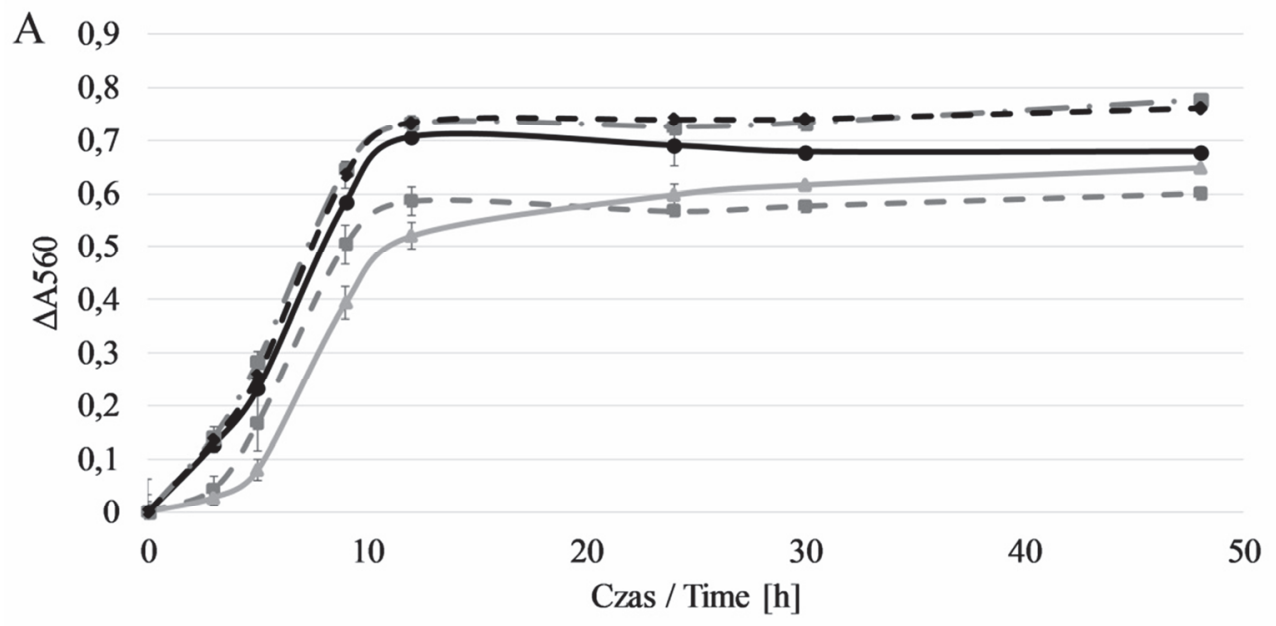




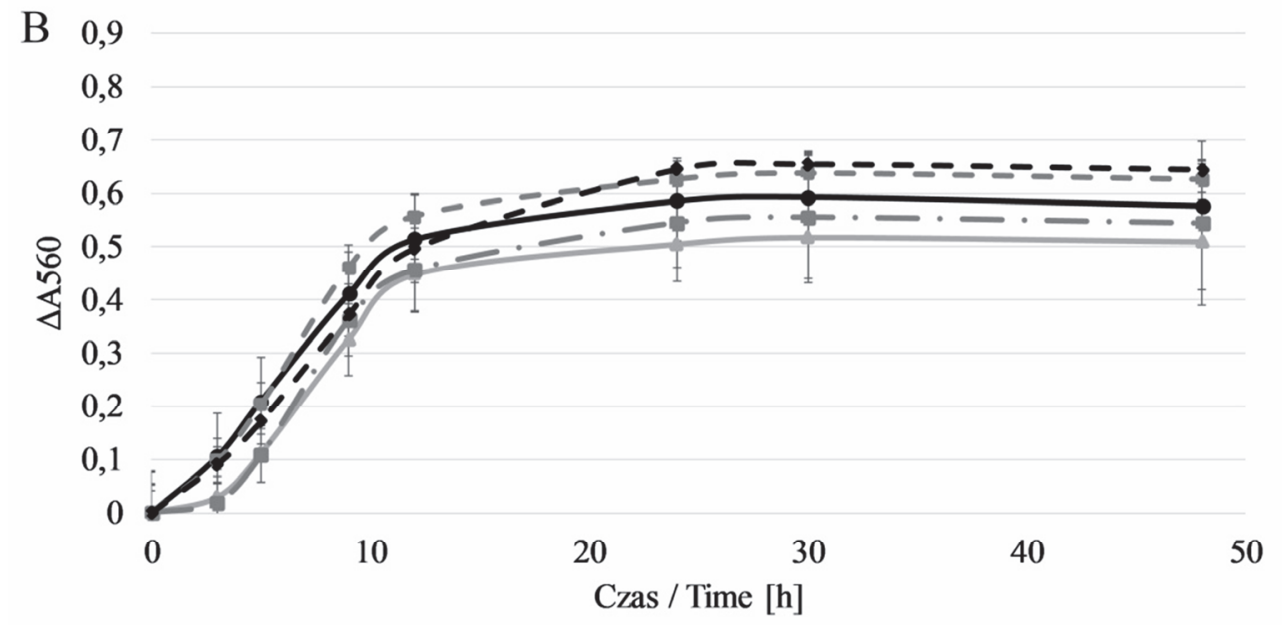

C $\quad 0,9$
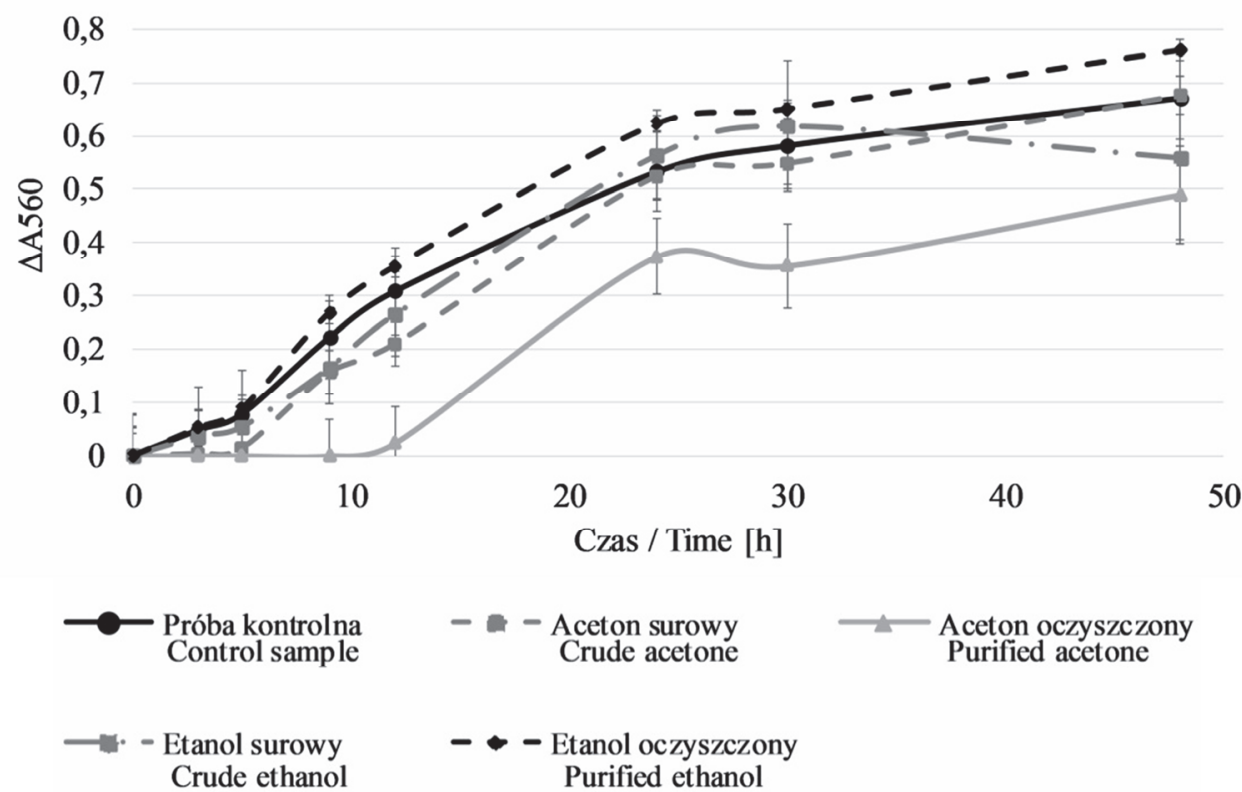

Objaśnienia / Explanatory notes:

Na rysunku przedstawiono wartości średnie i odchylenia standardowe (w postaci słupków błędu) / Figure shows mean values and standard deviations (presented as error bars).

Rys. 1. Przyrost biomasy bakterii z rodzaju Lactobacillus: A - Lb. acidophilus ŁOCK 0928, B - Lb. brevis ŁOCK 0944, C - Lb. casei ŁOCK 0979 w zależności od dodatku polifenoli w stężeniu $0,156 \mathrm{mg} / \mathrm{ml}$ zawartych w ekstraktach z wytłoków z pseudoowoców Rosa rugosa Thunb.

Fig. 1. Increase in biomass of Lactobacillus bacteria: A - Lb. acidophilus ŁOCK 0928, B - Lb.s brevis ŁOCK 0944, C - Lb. casei ŁOCK 0979 depending on polyphenols added at concentration of $0.156 \mathrm{mg} / \mathrm{ml}$ contained in extracts from Rosa rugosa Thunb. pseudofruit pomace 
Tabela 2. Wzrost bakterii Lactobacilllus spp. determinowany zawartością polifenoli w ekstraktach

Table 2. Growth Lactobacillus spp. bacteria dependent on content of polyphenols in extracts

\begin{tabular}{|c|c|c|c|c|c|}
\hline \multirow{4}{*}{$\begin{array}{l}\text { Szczep } \\
\text { Strain }\end{array}$} & \multirow{4}{*}{$\begin{array}{l}\text { Godzina } \\
\text { Hour }\end{array}$} & \multicolumn{4}{|c|}{ Przyrost biomasy / Biomass increase $[\Delta \mathrm{A} 560]$} \\
\hline & & \multicolumn{4}{|c|}{ Ekstrakt wodno-acetonowy / Water-acetone extract } \\
\hline & & \multicolumn{2}{|c|}{ Surowy / Crude } & \multicolumn{2}{|c|}{ Oczyszczony / Purified } \\
\hline & & $0,321 \mathrm{mg} / \mathrm{ml}$ & $0,625 \mathrm{mg} / \mathrm{ml}$ & $0,321 \mathrm{mg} / \mathrm{ml}$ & $0,625 \mathrm{mg} / \mathrm{ml}$ \\
\hline \multirow{7}{*}{$\begin{array}{c}\text { Lb. acidophilus } \\
\text { ŁOCK } 0928\end{array}$} & 3 & $0,076^{\mathrm{b}} \pm 0,012$ & $0 \pm 0$ & $0,056^{\mathrm{b}} \pm 0,051$ & $0 \pm 0$ \\
\hline & 5 & $0,171^{\mathrm{b}} \pm 0,007$ & $0^{\mathrm{a}} \pm 0$ & $0,146^{\mathrm{b}} \pm 0,074$ & $0,076^{\mathrm{a}, \mathrm{b}} \pm 0,003$ \\
\hline & 9 & $0,481^{\mathrm{b}} \pm 0,008$ & $0^{\mathrm{a}} \pm 0$ & $0,488^{b} \pm 0,139$ & $0,089^{\mathrm{a}, \mathrm{b}} \pm 0,004$ \\
\hline & 12 & $0,556^{\mathrm{b}} \pm 0,005$ & $0^{\mathrm{a}, \mathrm{b}} \pm 0$ & $0,575^{\mathrm{b}} \pm 0,121$ & $0,171^{\mathrm{a}, \mathrm{b}} \pm 0,004$ \\
\hline & 24 & $0,608^{b} \pm 0,005$ & $0,052^{\mathrm{a}, \mathrm{b}} \pm 0,012$ & $0,574^{\mathrm{b}} \pm 0,045$ & $0,213^{\mathrm{a}, \mathrm{b}} \pm 0,008$ \\
\hline & 30 & $0,635^{b} \pm 0,003$ & $0,152^{\mathrm{a}, \mathrm{b}} \pm 0,019$ & $0,583^{b} \pm 0,043$ & $0,235^{\mathrm{a}, \mathrm{b}} \pm 0,009$ \\
\hline & 48 & $0,651^{\mathrm{a}, \mathrm{b}} \pm 0,004$ & $0,157^{\mathrm{a}, \mathrm{b}} \pm 0,008$ & $0,623^{\mathrm{a}, \mathrm{b}} \pm 0,004$ & $0,028^{\mathrm{a}, \mathrm{b}} \pm 0,008$ \\
\hline \multirow{7}{*}{$\begin{array}{l}\text { Lb. brevis } \\
\text { ŁOCK } 0944\end{array}$} & 3 & $0 \pm 0$ & $0^{\mathrm{a}} \pm 0$ & $0^{\mathrm{b}} \pm 0$ & $0,058^{\mathrm{a}, \mathrm{b}} \pm 0,015$ \\
\hline & 5 & $0,023^{\mathrm{a}, \mathrm{b}} \pm 0,009$ & $0^{\mathrm{a}} \pm 0$ & $0^{\mathrm{a}, \mathrm{b}} \pm 0$ & $0,049^{\mathrm{a}, \mathrm{b}} \pm 0,011$ \\
\hline & 9 & $0,259^{\mathrm{a}, \mathrm{b}} \pm 0,056$ & $0^{\mathrm{a}} \pm 0$ & $0,043^{\mathrm{a}, \mathrm{b}} \pm 0,011$ & $0,052^{\mathrm{a}, \mathrm{b}} \pm 0,014$ \\
\hline & 12 & $0,348^{\mathrm{a}, \mathrm{b}} \pm 0,043$ & $0,039^{\mathrm{b}} \pm 0,019$ & $0,128^{\mathrm{a}, \mathrm{b}} \pm 0,009$ & $0,069^{b} \pm 0,012$ \\
\hline & 24 & $0,439^{\mathrm{a}, \mathrm{b}} \pm 0,018$ & $0,127^{\mathrm{a}, \mathrm{b}} \pm 0,005$ & $0,171^{\mathrm{a}, \mathrm{b}} \pm 0,009$ & $0,031^{\mathrm{a}, \mathrm{b}} \pm 0,017$ \\
\hline & 30 & $0,443^{\mathrm{a}, \mathrm{b}} \pm 0,017$ & $0,135^{\mathrm{a}, \mathrm{b}} \pm 0,001$ & $0,188^{\mathrm{a}, \mathrm{b}} \pm 0,025$ & $0,028^{\mathrm{a}, \mathrm{b}} \pm 0,018$ \\
\hline & 48 & $0,437^{\mathrm{a}, \mathrm{b}} \pm 0,016$ & $0,129^{\mathrm{a}, \mathrm{b}} \pm 0,005$ & $0,196^{\mathrm{a}, \mathrm{b}} \pm 0,009$ & $0,014^{\mathrm{a}, \mathrm{b}} \pm 0,013$ \\
\hline \multirow{7}{*}{$\begin{array}{c}\text { Lb. casei } \\
\text { ŁOCK } 0979\end{array}$} & 3 & $0 \pm 0$ & $0 \pm 0$ & $0^{\mathrm{b}} \pm 0$ & $0 \pm 0$ \\
\hline & 5 & $0 \pm 0$ & $0 \pm 0$ & $0^{\mathrm{b}} \pm 0$ & $0 \pm 0$ \\
\hline & 9 & $0 \pm 0$ & $0 \pm 0$ & $0^{\mathrm{b}} \pm 0$ & $0 \pm 0$ \\
\hline & 12 & $0 \pm 0$ & $0 \pm 0$ & $0^{\mathrm{b}} \pm 0$ & $0 \pm 0$ \\
\hline & 24 & $0,362^{\mathrm{a}, \mathrm{b}} \pm 0,039$ & $0,049^{\mathrm{a}, \mathrm{b}} \pm 0,041$ & $0,103^{\mathrm{a}, \mathrm{b}} \pm 0,036$ & $0^{\mathrm{a}} \pm 0$ \\
\hline & 30 & $0,392^{\mathrm{a}, \mathrm{b}} \pm 0,041$ & $0,119^{\mathrm{a}, \mathrm{b}} \pm 0,035$ & $0,124^{\mathrm{a}, \mathrm{b}} \pm 0,056$ & $0^{\mathrm{a}, \mathrm{b}} \pm 0$ \\
\hline & 48 & $0,513^{\mathrm{a}, \mathrm{b}} \pm 0,043$ & $0,164^{\mathrm{a}, \mathrm{b}} \pm 0,039$ & $0,169^{\mathrm{a}, \mathrm{b}} \pm 0,001$ & $0^{\mathrm{a}, \mathrm{b}} \pm 0$ \\
\hline \multirow{3}{*}{$\begin{array}{l}\text { Szczep } \\
\text { Strain }\end{array}$} & \multirow{3}{*}{$\begin{array}{c}\text { Godzina } \\
\text { Hour }\end{array}$} & \multicolumn{4}{|c|}{ Ekstrakt wodno-etanolowy / Water-ethanolic extract } \\
\hline & & \multicolumn{2}{|c|}{ Surowy / Crude } & \multicolumn{2}{|c|}{ Oczyszczony / Purified } \\
\hline & & $0,321 \mathrm{mg} / \mathrm{ml}$ & $0,625 \mathrm{mg} / \mathrm{ml}$ & $0,321 \mathrm{mg} / \mathrm{ml}$ & $0,625 \mathrm{mg} / \mathrm{ml}$ \\
\hline \multirow{7}{*}{$\begin{array}{l}\text { Lb. acidophilus } \\
\text { ŁOCK } 0928\end{array}$} & 3 & $0^{\mathrm{b}} \pm 0$ & $0 \pm 0$ & $0^{\mathrm{b}} \pm 0$ & $0 \pm 0$ \\
\hline & 5 & $0,066^{\mathrm{a}, \mathrm{b}} \pm 0,005$ & $0 \pm 0$ & $0^{\mathrm{a}, \mathrm{b}} \pm 0$ & $0^{\mathrm{b}} \pm 0$ \\
\hline & 9 & $0,418^{\mathrm{a}, \mathrm{b}} \pm 0,005$ & $0 \pm 0$ & $0,015^{\mathrm{a}, \mathrm{b}} \pm 0,009$ & $0,011^{\mathrm{b}} \pm 0,009$ \\
\hline & 12 & $0,509^{\mathrm{a}, \mathrm{b}} \pm 0,003$ & $0,148^{\mathrm{b}} \pm 0,039$ & $0,149^{\mathrm{a}, \mathrm{b}} \pm 0,021$ & $0,085^{\mathrm{b}} \pm 0,039$ \\
\hline & 24 & $0,529^{\mathrm{a}, \mathrm{b}} \pm 0,004$ & $0,224^{\mathrm{a}, \mathrm{b}} \pm 0,011$ & $0,322^{\mathrm{a}, \mathrm{b}} \pm 0,008$ & $0,118^{\mathrm{a}, \mathrm{b}} \pm 0,022$ \\
\hline & 30 & $0,542^{\mathrm{a}, \mathrm{b}} \pm 0,002$ & $0,249^{\mathrm{a}, \mathrm{b}} \pm 0,031$ & $0,347^{\mathrm{a}, \mathrm{b}} \pm 0,003$ & $0,132^{\mathrm{a}, \mathrm{b}} \pm 0,012$ \\
\hline & 48 & $0,583^{\mathrm{a}, \mathrm{b}} \pm 0,007$ & $0,222^{\mathrm{a}, \mathrm{b}} \pm 0,035$ & $0,389^{\mathrm{a}, \mathrm{b}} \pm 0,003$ & $0,161^{\mathrm{a}, \mathrm{b}} \pm 0,012$ \\
\hline \multirow{4}{*}{$\begin{array}{l}\text { Lb. brevis } \\
\text { ŁOCK } 0944\end{array}$} & 3 & $0 \pm 0$ & $0 \pm 0$ & $0,058^{b} \pm 0,039$ & $0^{\mathrm{b}} \pm 0$ \\
\hline & 5 & $0^{\mathrm{a}, \mathrm{b}} \pm 0$ & $0 \pm 0$ & $0,154^{\mathrm{a}, \mathrm{b}} \pm 0,039$ & $0^{\mathrm{b}} \pm 0$ \\
\hline & 9 & $0,135^{\mathrm{a}, \mathrm{b}} \pm 0,024$ & $0^{\mathrm{a}} \pm 0$ & $0,365^{\mathrm{a}, \mathrm{b}} \pm 0,024$ & $0,102^{\mathrm{a}, \mathrm{b}} \pm 0,015$ \\
\hline & 12 & $0,205^{\mathrm{a}, \mathrm{b}} \pm 0,023$ & $0^{\mathrm{a}, \mathrm{b}} \pm 0$ & $0,456^{\mathrm{a}, \mathrm{b}} \pm 0,021$ & $0,182^{\mathrm{a}, \mathrm{b}} \pm 0,017$ \\
\hline
\end{tabular}




\begin{tabular}{|c|c|c|c|c|c|}
\hline & 24 & $0,269^{\mathrm{a}, \mathrm{b}} \pm 0,017$ & $0^{\mathrm{a}, \mathrm{b}} \pm 0$ & $0,496^{\mathrm{a}, \mathrm{b}} \pm 0,012$ & $0,202^{\mathrm{a}, \mathrm{b}} \pm 0,024$ \\
\hline & 30 & $0,269^{\mathrm{a}, \mathrm{b}} \pm 0,018$ & $0^{\mathrm{a}, \mathrm{b}} \pm 0$ & $0,483^{\mathrm{a}, \mathrm{b}} \pm 0,018$ & $0,205^{\mathrm{a}, \mathrm{b}} \pm 0,023$ \\
\hline & 48 & $0,236^{\mathrm{a}, \mathrm{b}} \pm 0,021$ & $0^{\mathrm{a}, \mathrm{b}} \pm 0$ & $0,503^{\mathrm{a}, \mathrm{b}} \pm 0,026$ & $0,183^{\mathrm{a}, \mathrm{b}} \pm 0,023$ \\
\hline \multirow{7}{*}{$\begin{array}{l}\text { Lb. casei } \\
\text { ŁOCK } 0979\end{array}$} & 3 & $0 \pm 0$ & $0 \pm 0$ & $0,058^{\mathrm{b}} \pm 0,039$ & $0^{\mathrm{b}} \pm 0$ \\
\hline & 5 & $0^{\mathrm{a}} \pm 0$ & $0 \pm 0$ & $0,051^{\mathrm{a}, \mathrm{b}} \pm 0,008$ & $0 \pm 0$ \\
\hline & 9 & $0^{\mathrm{a}} \pm 0$ & $0 \pm 0$ & $0,272^{\mathrm{a}, \mathrm{b}} \pm 0,028$ & $0 \pm 0$ \\
\hline & 12 & $0^{\mathrm{a}} \pm 0$ & $0 \pm 0$ & $0,391^{\mathrm{a}, \mathrm{b}} \pm 0,021$ & $0 \pm 0$ \\
\hline & 24 & $0^{\mathrm{a}, \mathrm{b}} \pm 0$ & $0^{\mathrm{b}} \pm 0$ & $0,544^{\mathrm{a}, \mathrm{b}} \pm 0,008$ & $0,008 \pm 0,07$ \\
\hline & 30 & $0^{\mathrm{a}, \mathrm{b}} \pm 0$ & $0^{\mathrm{a}, \mathrm{b}} \pm 0$ & $0,567^{\mathrm{a}, \mathrm{b}} \pm 0,013$ & $0,055^{\mathrm{a}, \mathrm{b}} \pm 0,019$ \\
\hline & 48 & $0^{\mathrm{a}, \mathrm{b}} \pm 0$ & $0^{\mathrm{a}, \mathrm{b}} \pm 0$ & $0,567^{\mathrm{a}, \mathrm{b}} \pm 0,017$ & $0,143^{\mathrm{a}, \mathrm{b}} \pm 0,021$ \\
\hline
\end{tabular}

Objaśnienia jak pod tab. 1. / Explanatory notes as in Tab. 1.

Polifenole w stężeniu $0,156 \mathrm{mg} / \mathrm{ml}$ zawarte w ekstraktach z wytłoków z pseudoowoców Rosa rugosa Tunb. oddziaływały również dwojako na przyrost biomasy bakterii $L b$. casei ŁOCK 0979 - stymulowały ten przyrost lub były czynnikiem obniżającym stopień namnożenia biomasy w zależności od zastosowanej procedury ekstrakcji. Różnice we wzroście bakterii z dodatkiem ekstraktów z wytłoków z pseudoowoców Rosa rugosa Thunb. widoczne były od początku prowadzenia hodowli. W 24 godzinie hodowli ekstrakt wodno-etanolowy oczyszczony spowodował, że przyrost biomasy był większy o ok. $16 \% \mathrm{w}$ stosunku do hodowli kontrolnej. Z kolei ekstrakty: wodno-acetonowy surowy i wodno-etanolowy surowy w stężeniu $0,156 \mathrm{mg} / \mathrm{ml} \mathrm{nie}$ wpływały znacząco na przyrost biomasy bakterii $L$ b. casei ŁOCK 0979. Polifenole zawarte w ekstrakcie wodno-actonowym oczyszczonym do 12 godziny hodowli hamowały przyrost biomasy bakterii $L b$. casei ŁOCK 0979. Po 48-godzinnej inkubacji stopień namnożenia biomasy w hodowli z dodatkiem ekstraktu był niższy o ok. $30 \%$ (rys. 1C).

Zastosowanie dwukrotnie wyższego stężenia polifenoli $(0,313 \mathrm{mg} / \mathrm{ml}) \mathrm{w}$ ekstrakcie wodno-etanolowym oczyszczonym nie wpłynęło znacząco na wzrost bakterii Lactobacillus casei LOCK 0979. W przypadku pozostałych trzech badanych ekstraktów polifenole w nich zawarte wpłynęly na ograniczenie przyrostu biomasy bakterii Lactobacillus casei ŁOCK 0979. Stopień namnożenia biomasy był o ok. $24 \%$ mniejszy przy stosowaniu dodatku ekstraktu wodno-acetonowego surowego i o ok. $33 \%$ mniejszy w obecności ekstraktu wodno-acetonowego oczyszczonego. Z kolei ekstrakt wodnoetanolowy surowy o stężeniu polifenoli $0,313 \mathrm{mg} / \mathrm{ml}$ uniemożliwił wzrost bakterii Lactobacillus casei ŁOCK 0979 (tab. 2).

Przy stężeniu polifenoli na poziomie $0,625 \mathrm{mg} / \mathrm{ml}$ każdy z czterech ekstraktów z wytłoków Rosa rugosa Thunb. uniemożliwiał rozwój bakterii Lactobacillus casei ŁOCK 0979.

Mimo że większość polifenoli spożywanych wraz z pokarmem roślinnym zostaje bezpośrednio wchłonięta po zjedzeniu, duża część wtórnych metabolitów roślin trafia 
do jelit, gdzie w znacznym stopniu odpowiada za modulację mikroflory. Wśród grupy polifenoli, które wywierają wpływ na mikroflorę jelitową ssaków wyróżnia się: polifenole glikozylowane ramnozą, estry kwasu hydroksycynamonowego, lignany, czy procyjanidyny [1]. Ponadto bakterie jelitowe zdolne są do metabolizmu polifenoli, takich jak flawan-3-ol i mogą być czynnikiem wpływającym na powstawanie nowych związków fenolowych (,in situ”) - niekiedy cechujących się wyższą biodostępnością niż substraty, z których zostały utworzone [19].

W badanych ekstraktach oznaczono zawartość procyjanidyn i wolnych katechin, które uznawane są za polifenole wpływające na mikroflorę jelit. Bakterie z rodzaju Lactobacillus są typowymi przedstawicielami mikroflory: jamy ustnej, żołądka, jelita czczego i krętego, dwunastnicy oraz okrężnicy. Tym samym możliwe jest, aby niestrawione polifenole docierające do poszczególnych odcinków przewodu pokarmowego człowieka w znacznym stopniu wpływały na stopień namnożenia bytujących w nim bakterii. Niemniej jednak odpowiedź bakterii z rodzaju Lactobacillus jest zazwyczaj cechą szczepową. Zależy również od grupy związków polifenolowych oraz ewentualnych uzdolnień metabolicznych bakterii.

Niewchłonięte polifenole mogą działać jak aktywatory bądź inhibitory wybranych grup mikroorganizmów. W zależności od struktury (podstawniki pierścieni aromatycznych) i stężenia mogą selektywnie hamować rozwój patogenów, a stymulować wzrost bakterii komensalnych - w tym także szczepów uznanych za probiotyczne [5, 14, 15]. Z wielu badań przeprowadzonych na mikroflorze jelitowej człowieka i ssaków (szczurów, świń) wynika, że polifenole mają korzystny wpływ na wzrost bakterii z rodzaju Lactobacillus [7, 26, 27, 28]. Rodríguez i wsp. [20] w swoich badaniach przedstawili aktywność enzymatyczną bakterii Lactobacillus plantarum, dzięki której możliwe jest degradowanie niektórych związków polifenolowych. Landete i wsp. [13] dowiedli, że Lactobacillus brevis wykazuje aktywność syntezy dekarboksylazy kwasu fenolowego. Z kolei Tabasco i wsp. [23] wykazali, że flawan-3-ol izolowany z nasion winogron w stężeniu $1 \mathrm{mg} / \mathrm{ml}$ oraz $0,5 \mathrm{mg} / \mathrm{ml}$ w znacznym stopniu ogranicza wzrost bakterii Lactobacillus gasseri LC9, Lactobacillus acidophilus LA-5 i Lactobacillus fermentum PNA1. Co ciekawe, flawan-3ol izolowany z pestek winogron w stężeniu $0,25 \mathrm{mg} / \mathrm{ml}$ może stać się czynnikiem obniżającym stopień namnożenia biomasy bakterii: Lactobacillus casei LC-01 i Lactobacillus plantarum CIC17, a jednocześnie jest zdolny do stymulacji wzrostu bakterii Lactobacillus casei IFPL7190 i Lactobacillus plantarum CLB7. Niekiedy również flawon-3-ol izolowany z pestek winogron zupełnie nie wpływa na stopień namnożenia biomasy bakterii takich, jak Lactobacillus bulgaricus LBY-27. Tym samym można zauważyć, że odpowiedź bakterii z rodzaju Lactobacillus na dodatek do podłoża hodowlanego polifenoli izolowanych ze środowiska naturalnego jest cechą indywidualną (zależną od gatunku, a nawet szczepu badanych bakterii). 
Na wzrost bakterii fermentacji mlekowej w dużej mierze wpływ mogły mieć różne grupy polifenoli zawarte w ekstraktach. Nawet niewielkie różnice w składach ekstraktów oraz stężeniach polifenoli powodowały, że reakcja bakterii z rodzaju Lactobacillus była odpowiedzią szczepową. Dalsza analiza interakcji między polifenolami zawartymi w wytłokach z pseudoowoców Rosa rugosa Thunb. a bakteriami z rodzaju Lactobacillus powinna dotyczyć badania różnic we wzroście bakterii w zależności od stężenia polifenoli w podłożu hodowlanym. Tym samym zostałaby określona aktywność metaboliczna badanych szczepów bakterii Lactobacillus sp.

\section{Wnioski}

1. Duża zawartość związków polifenolowych w otrzymanych ekstraktach z wytłoków z róży potwierdza, że wytłoki te mogą stanowić wartościowy surowiec do pozyskiwania tej grupy związków.

2. Ekstrakty, które dodatkowo poddano oczyszczaniu techniką chromatografii kolumnowej, zawierają więcej wybranych grup związków polifenolowych niż ekstrakty surowe, zliofilizowane $\mathrm{z}$ pominięciem tego etapu.

3. Stężenie polifenoli na poziomie $0,156 \mathrm{mg} / \mathrm{ml}$ ma prebiotyczny wpływ na bakterie z rodzaju Lactobacillus, natomiast polifenole w stężeniu powyżej $0,156 \mathrm{mg} / \mathrm{ml}$, zawarte w ekstraktach z wytłoków z pseudoowoców Rosa rugosa Thunb., działają jako czynnik ograniczający rozwój bakterii z rodzaju Lactobacillus.

4. Bakterie z rodzaju Lactobacillus wykazują wyższą zdolność do tolerancji polifenoli obecnych $\mathrm{w}$ liofilizowanych ekstraktach: wodno-etanolowym oczyszczonym i wodno-acetonowym surowym niż w ekstraktach: wodno-etanolowym surowym i wodno-acetonowym oczyszczonym.

5. Bakterie z rodzaju Lactobacillus wykazują największą zdolność do tolerancji polifenoli zawartych w zliofilizowanym oczyszczonym ekstrakcie etanolowym.

\section{Literatura}

[1] Aura A.-M.: Microbial metabolism of dietary phenolic compounds in the colon. Phytochem. Rev., 2008, 7 (3), 407-429.

[2] Buchwald W., Zieliński J., Mścisz A., Adamczak A., Mrozikiewicz P.M.: Aktualny stan i perspektywy badan róż owocowych. Herb. Pol., 2007, 53 (1), 85-92.

[3] Cendrowski A., Ścibisz I., Mitek M., Kieliszek M., Kolniak-Ostek J.: Profile of the phenolic compounds of Rosa rugosa petals. J. Food Qual., 2017, \#7941347. DOI: 10.1155/2017/7941347.

[4] Chrubasik C., Roufogalis B.D., Muller-Ladner U., Chrubasik S.: A systematic review on the Rosa canina effect and efficacy profiles. Phytother. Res., 2008, 22 (6), 725-733.

[5] Cueva C., Moreno-Arribas M.V., Martin-Alvarez P.J., Bills G., Vicente M.F., Basilio A., Rivas C.L., Requena T., Rodriguez J.M., Bartolome B.: Antimicrobial activity of phenolic acids against commensal, probiotic and pathogenic bacteria. Rec. Microbiol., 2010, 161 (5), 372-382. 
[6] Cunja V., Mikulic-Petkovsek M., Zupan A., Stampar F., Schmitzer V.: Frost decreases content of sugars, ascorbic acid and some quercetin glycosides but stimulates selected carotenes in Rosa canina hips. J. Plant Physiol., 2015, 178, 55-63.

[7] Dolara P., Luceri C., de Filippo C., Femia A.P., Giovannelli L., Caderni G., Cecchini C., Silvi S., Orpianesi C., Cresci A.: Red wine polyphenols influence carcinogenesis, intestinal microflora, oxidative damage and gene expression profiles of colonic mucosa in F344 rats. Mutat. Res., 2005, 591 (1-2), 237-246.

[8] Fecka I.: Qualitative and quantitative determination of hydrolysable tannins and other polyphenols in herbal products from meadowsweet and dog rose. Phytochem. Anal., 2009, 20 (3), 177-190.

[9] Grys A.: Dzika Róża (Rosa canina L.) - chemizm i zastosowanie w lecznictwie. Post. Fitoter., 2009, 4, 245-247.

[10] Klewicka E., Libudzisz Z., Śliżewska K., Otlewska A.: Nowy szczep bakterii mlekowych Lactobacillus brevis. Patent Polska 2013 (PL 214504, B1).

[11] Koponen J.M., Happonen A.M., Mattila P.H., Torronen A.R.: Contents of anthocyanins and ellagitannins in selected foods consumed in Finland. J. Agric. Food Chem., 2007, 55 (4), 1612-1619.

[12] Kosmala M., Zdunczyk Z., Kolodziejczyk K., Klimczak E., Juskiewicz J., Zdunczyk P.: Chemical composition of polyphenols extracted from strawberry pomace and their effect on physiological properties of diets supplemented with different types of dietary fibre in rats. Eur. J. Nutr., 2014, 53 (2), 521-532.

[13] Landete J.M., Rodriguez H., Curiel J.A., de las Rivas B., Mancheno J.M., Munoz R.: Gene cloning, expression, and characterization of phenolic acid decarboxylase from Lactobacillus brevis RM84. J. Ind. Microbiol. Biotechnol., 2010, 37 (6), 617-624.

[14] Larrosa M., Yanez-Gascon M.J., Selma M.V., Gonzalez-Sarrias A., Toti S., Ceron J.J., TomasBarberan F., Dolara P., Espin J.C.: Effect of a low dose of dietary resveratrol on colon microbiota, inflammation and tissue damage in a DSS-induced colitis rat model. J. Agric. Food Chem., 2009, 57 (6), 2211-2220.

[15] Lee H.C., Jenner A.M., Low C.S., Lee Y.K.: Effect of tea phenolics and their aromatic fecal bacterial metabolites on intestinal microbiota. Res. Microbiol., 2006, 157 (9), 876-884.

[16] Milala J., Sójka M., Król K., Buczek M.: Charakterystyka składu chemicznego owoców Rosa pomifera 'Karpatia'. Żywność. Nauka. Technologia. Jakość, 2013, 5 (90), 154-167.

[17] Nadpal J.D., Lesjak M.M., Šibul F.S., Anačkov G.T., Četojević-Simin D.D., Mimica-Dukić N.M., Beara I.N.: Comparative study of biological activities and phytochemical composition of two rose hips and their preserves: Rosa canina L. and Rosa arvensis Huds. Food Chem, 2016, 192, 907-914.

[18] Nowak D., Nienautowska A.: Wpływ warunków liofilizacji na właściwości suszonego przecieru z owoców dzikiej róży. Post. Techn. Przetw. Spoż., 2017, 1, 60-65.

[19] Requena T., Monagas M., Pozo-Bayón M.A., Martín-Álvarez P.J., Bartolomé B., del Campo R., Ávila M., Martínez-Cuesta M.C., Peláez C., Moreno-Arribas M.V.: Perspectives of the potential implications of wine polyphenols on human oral and gut microbiota. Trends Food Sci. Technol., 2010, 21 (7), 332-344.

[20] Rodríguez H., Curiel J.A., Landete J.M., de las Rivas B., de Felipe F.L., Gómez-Cordovés C., Mancheño J.M., Muñoz R.: Food phenolics and lactic acid bacteria. Int. J. Food Microbiol., 2009, 132 (2), 79-90.

[21] Skręty J., Gramza-Michałowska A., Sidor A., Korczak J.: Wpływ wybranych warunków przechowywania na zawartość witaminy $\mathrm{C}$ w owocach róży pomarszczonej Rosa rugosa. Probl. Hig. Epidemiol., 2013, 94 (4), 869-872.

[22] Sołtys-Lelek A.: Chorologia krytycznych rodzajów - Crataegus L., Rosa L., Rubus L. na Wyżynie Krakowsko-Częstochowskiej. Prądnik. Prace i Materiały Muzeum im. Prof. W. Szafera, 2011, 21, 5109. 
[23] Tabasco R., Sanchez-Patan F., Monagas M., Bartolome B., Victoria Moreno-Arribas M., Pelaez C., Requena T.: Effect of grape polyphenols on lactic acid bacteria and bifidobacteria growth: Resistance and metabolism. Food Microbiol., 2011, 28 (7), 1345-1352.

[24] Teleszko M., Wojdyło A., Oszmiański J.: Zawartość kwasu elagowego i spolimeryzowanych proantocyjanidyn w pseudoowocach wybranych gatunków róż. Żywność. Nauka. Technologia. Jakość, 2012, 5 (84), 37-46.

[25] Turan I., Demir S., Kilinc K., Yaman S.O., Misir S., Kara H., Genc B., Mentese A., Aliyazicioglu Y., Deger O.: Cytotoxic effect of Rosa canina extract on human colon cancer cells through repression of telomerase expression. J. Pharm. An., 2018, 8 (6), 394-399.

[26] Tzounis X., Rodriguez-Mateos A., Vulevic J., Gibson G.R., Kwik-Uribe C., Spencer J.P.: Prebiotic evaluation of cocoa-derived flavanols in healthy humans by using a randomized, controlled, doubleblind, crossover intervention study. Am. J. Clin. Nutr., 2011, 93 (1), 62-72.

[27] Tzounis X., Vulevic J., Kuhnle G.G., George T., Leonczak J., Gibson G.R., Kwik-Uribe C., Spencer J.P.: Flavanol monomer-induced changes to the human faecal microflora. Br. J. Nutr., 2008, 99 (4), 782-792.

[28] Viveros A., Chamorro S., Pizarro M., Arija I., Centeno C., Brenes A.: Effects of dietary polyphenolrich grape products on intestinal microflora and gut morphology in broiler chicks. Poultry Sci., 2011, 90 (3), 566-578.

[29] Wałejko A.: Właściwości przeciwutleniające owoców róży pomarszczonej (Rosa rugosa Thunb.). W: Zagadnienia aktualnie poruszane przez młodych naukowców 2. Tom I. Red. M. Kuczera, K. Piech. Wyd. Creativetime, Kraków 2015, ss. 118-121.

[30] Wiśniewska-Grzeszkiewicz H.: Róże owocowe. Hasło Ogrodnicze, 1999, (10), 260-261.

[31] Yilmaz S.O., Ercisli S.: Antibacterial and antioxidant activity of fruits of some rose species from Turkey. Rom. Biotechnol. Lett., 2011, 16 (4), 6407-6411.

\title{
IMPACT OF POLYPHENOLS FROM ROSA RUGOSA THUNB. PSEUDOFRUITS POMACE ON GROWTH OFLACTOBACILLUS BACTERIA
}

\author{
S u m m a r y
}

As secondary metabolites of plants, polyphenols constitute a basic barrier for microflora that is considered to be morbific and pathogenic (viruses, fungi, bacteria). When consumed with food, the polyphenols are able to produce many positive effects in the organisms of mammals (animals and human) and birds. Attributed to them are not only antioxidant properties, but also blood pressure lowering, antiinflammatory and antimicrobial properties. Thus, when reaching the intestines, the undigested polyphenols are responsible, to a large extent, for the modulation of intestinal microflora (including bacteria of the Lactobacillus genus). Rosa rugosa Thunb. is one of the plants that contains large amounts of polyphenolic compounds; it is one of the most popular species of wild rose occurring in Poland.

The objective of the research study was to assess the prebiotic potential of crude and purified polyphenol extracts obtained from Rosa rugosa Thunb. pseudofruit pomace towards bacteria of the Lactobacillus genus (including strains with the verified probiotic properties). The predominant groups of polyphenols present in the extracts were ellagotannins and procyanidins. Also free ellagic acid, flavonols, and catechins were present in the extracts. In addition, the purified extracts were characterised by a much higher content of polyphenols in comparison to crude extracts. Furthermore, studies were performed on the prebiotic potential of lyophilized extracts towards bacteria of the Lactobacillus genus (including the Lactobacillus brevis ŁOCK 0944 strain with the verified probiotic properties) using turbidimetric method. Only polyphenols at a concentration of $0.156 \mathrm{mg} / \mathrm{ml}$ has a prebiotic potential towards the Lactobacillus bacteria. 
Higher concentrations of polyphenols contained in Rosa rugosa Thunb. pseudofruit acted as a factor limiting the increase in the biomass of Lactobacillus spp. bacteria.

Key words: Lactobacillus sp., bacteria growth, Rosa rugosa Thunb., polyphenols 